\title{
Kemampuan reproduksi dan riwayat hidup kutukebul Bemisia tabaci (Gennadius) dengan dan tanpa kopulasi pada tanaman cabai merah dan tomat
}

\author{
The reproductive ability and life history of Bemisia tabaci \\ (Gennadius) with and without copulation on chili pepper and tomato \\ Purnama Hidayat $^{{ }^{*}}$, Rika Ludji ${ }^{2}$, Nina Maryana ${ }^{1}$ \\ ${ }^{1}$ Departemen Proteksi Tanaman, Fakultas Pertanian, Institut Pertanian Bogor \\ Jalan Kamper, Kampus IPB Dramaga, Bogor 16680 \\ ${ }^{2}$ Fakultas Pertanian, Universitas Nusa Cendana \\ Jalan Adi Sucipto, Penfui, Kupang 85001
}

(diterima Mei 2019, disetujui Oktober 2020)

\begin{abstract}
ABSTRAK
Kutukebul Bemisia tabaci (Gennadius) merupakan hama kosmopolitan pada berbagai jenis tanaman pertanian. Kutukebul dapat menyebabkan kerusakan tanaman dengan cara mengisap bagian tanaman menggunakan stilet dan sebagai vektor virus tanaman. Tanaman cabai merah (Capsicum annuиm) dan tomat (Solanum lycopersicum) merupakan tanaman hortikultura penting yang sering diserang oleh B. tabaci. Kutukebul diketahui dapat bereproduksi dengan kopulasi yang menghasilkan keturunan jantan dan betina serta tanpa kopulasi yang menghasilkan keturunan jantan. Tujuan penelitian ini untuk mengetahui kemampuan reproduksi kutukebul B. tabaci yang berkopulasi dan tidak kopulasi pada tanaman cabai merah dan tomat. Imago $B$. tabaci diambil dari tempat pemeliharaan di rumah kaca Cikabayan, IPB Dramaga. Satu imago betina yang baru keluar dari pupa atau nimfa instar akhir diinfestasikan pada tanaman cabai merah dan tomat yang ditanam dalam polibag untuk mengetahui keturunan $B$. tabaci yang dihasilkan tanpa kopulasi. Pengujian untuk mengamati reproduksi $B$. tabaci yang berkopulasi sama dengan perlakuan tanpa kopulasi, hanya saja pada tanaman cabai merah dan tomat diinfestasikan satu pasang imago (jantan dan betina). Masing-masing perlakuan diulang 5 kali. Pengamatan dilakukan setiap hari terhadap jumlah telur yang dihasilkan oleh satu imago betina setiap harinya, masa inkubasi telur, lamanya periode nimfa untuk tiap-tiap instar, pupa, dan imago. Penelitian ini menunjukkan bahwa keperidian $B$. tabaci yang bereproduksi dengan kopulasi dan tidak kopulasi pada tanaman tomat lebih tinggi dibandingkan pada tanaman cabai, namun tidak ada perbedaan siklus hidup dan nisbah kelaminnya.
\end{abstract}

Kata kunci: Aleyrodidae, arenotoki, nisbah kelamin, Solanaceae

\begin{abstract}
The sweet potato whitefly, Bemisia tabaci (Gennadius) is a cosmopolitan pest on various types of agricultural crops. The whitefly is able to cause damage to plants by directly consuming plant parts using stylet and as a vector of plant viruses. Red chili (Capsicum annuum) and tomato (Solanum lycopersicum) plants are important horticultural plants that are often infested by B. tabaci. Whiteflies are known to reproduce with copulation that produce male and female offspring and without copulation that produce male offspring. The purpose of this study was to determine the reproduction ability of $B$. tabaci with and without copulation in red chili pepper and tomato. Adult of B. tabaci was taken from a greenhouse in Cikabayan, IPB Dramaga. One female who just emerged from the pupa or final instar nymph was invested in red chilli and tomato plants in polybags to
\end{abstract}

\footnotetext{
*Penulis korespondensi: Purnama Hidayat. Departemen proteksi Tanaman, Fakultas Pertanian, Institut Pertanian Bogor

Jalan Kamper, Kampus IPB Dramaga, Bogor 16680, Tel: 0251-8629364, Faks: 0251-8629362, Email: phidayat@apps.ipb.ac.id
} 
determine the B. tabaci offspring produced without copulation. The same method was also done for whitefly with copulation, but using a pair of adult whitefly (male and female). Each treatment was repeated 5 times. Observations were made every day on the number of eggs produced by one female adult per day, the egg incubation period, the length of the nymph period for each instar, pupa, and adult. The results of this study showed that the fertility of $B$. tabaci which reproduces with and without copulation in tomato plants was higher than in chili pepper plants, but there was no difference in life cycle and sex ratio.

Key words: Aleyrodidae, arrhenotokous, sex ratio, Solanaceae

\section{PENDAHULUAN}

Kutukebul Bemisia tabaci (Gennadius) merupakan serangga polifag yang berperan sebagai hama dan vektor virus pada berbagai jenis tanaman budi daya, seperti pada tanaman pangan, sayuran, dan tanaman hias. B. tabaci menyerang lebih dari 600 spesies tanaman dari berbagai famili. Kutukebul dapat menularkan virus dari gulma ke tanaman budi daya (Bos 1981). B. tabaci merupakan vektor lebih dari 60 virus tanaman dalam Genera Geminivirus, Closterovirus, Nepovirus, Carlavirus, Potyvirus, dan virus DNA yang berbentuk batang (Gangwar \& Gangwar 2018).

Cabai merah (Capsicum annuum) dan tomat (Solanum lycopersicum) merupakan tanaman hortikultura bernilai ekonomis yang sering diserang oleh kutukebul dan menyebabkan kerugian yang cukup besar. Salah satu penyakit pada tanaman cabai merah dan tomat yang ditularkan oleh kutukebul adalah penyakit keriting daun. Serangan penyakit tersebut sangat merugikan petani karena dapat menyebabkan penurunan hasil produksi yang cukup tinggi (Sebayang 2013). Penurunan hasil produksi akibat penyakit keriting daun pada tanaman di daerah Bogor, Jawa Barat, dan sekitarnya dapat mencapai 50-70\% (Sudiono et al. 2005). Di Indonesia kejadian penyakit keriting daun akibat infeksi Begomovirus pada tanaman tomat dapat mencapai $90-100 \%$ dan hal ini dapat menyebabkan penurunan hasil hingga 50-100\% (Santoso et al. 2008).

Kutukebul juga merupakan vektor virus penyakit kuning pada tanaman hortikultura. Penyebaran virus pada tanaman tomat, kedelai, cabai, dan beberapa tanaman lainnya dipengaruhi oleh keberadaan populasi kutukebul di lapangan (Sudiono et al. 2005). Peningkatan kelimpahan populasi kutukebul pada tanaman tomat menyebabkan peningkatan kejadian penyakit kuning sebesar 87,37\% (Narendra et al. 2017). Hal ini didukung adanya kemampuan kutukebul yang dapat bereproduksi baik dengan cara tanpa kopulasi maupun dengan kopulasi. Selain itu, kutukebul memiliki kemampuan reproduksi yang tinggi sehingga populasinya cepat meningkat (Kalshoven 1981).

Imago betina kutukebul menghisap tanaman budi daya maupun gulma yang berbeda untuk mendapatkan nutrisi yang cukup, baik dari segi kualitas maupun kuantitas. Hal ini karena masingmasing tanaman memiliki kandungan nutrisi yang bebeda. Suatu jenis tumbuhan tertentu mungkin sesuai bagi kutukebul untuk sekedar bertahan hidup dan jenis tumbuhan lainnya sesuai bagi kutukebul untuk dapat menghasilkan telur yang lebih banyak (Costa \& Brown 1991).

Informasi tentang reproduksi dan keperidian kutukebul ini merupakan informasi dasar yang diperlukan dalam menelaah perubahan kepadatan dan laju pertumbuhan maupun penurunan populasi. Pertumbuhan populasi dapat diketahui apabila jumlah keturunan yang dihasilkan oleh imago betina pada interval waktu tertentu diketahui. Informasi tentang perbedaan keperidian antara imago betina yang bereproduksi tanpa kopulasi dan dengan kopulasi masih terbatas. Oleh sebab itu, perlu dikaji lebih lanjut tentang keperidian kutukebul baik tanpa kopulasi maupun dengan kopulasi.

Kutukebul bereproduksi secara arrenotoki, kecuali satu spesies Parabemisia myricae (Kuwana) yang bereproduksi secara telitoki yang keturunannya semua betina (Byrne \& Thomas 1991; Byrne \& Devonshire 1996). Menurut Gullan \& Martin (2009), serangga Subordo Sternorrhyncha bereproduksi secara arrenotoki. Arrenotoki adalah salah satu bentuk partenogenesis apabila telur dibuahi menjadi keturunan betina dan apabila telur tidak dibuahi keturunan menjadi jantan. Berbagai publikasi menunjukkan bahwa 
B. tabaci bereproduksi dengan arrenotoki (Bonato et al. 2006), namun tidak dijelaskan apakah tanaman inang dapat mempengaruhi kemampuan reproduksinya.

Tujuan penelitian ini untuk mengetahui jumlah keturunan, lama siklus hidup, keberhasilan hidup, serta nisbah kelamin keturunan $B$. tabaci yang dihasilkan dengan kopulasi dan tanpa kopulasi pada tanaman cabai merah dan tomat.

\section{BAHAN DAN METODE}

Penelitian ini dilaksanakan di Laboratorium Biosistematika Serangga, Departemen Proteksi Tanaman, Institut Pertanian Bogor yang berlangsung dari bulan April sampai September 2010.

\section{Persiapan tanaman inang}

Sebelum dilakukan pengujian, tanaman cabai merah dan tomat ditanam terlebih dahulu sebagai tanaman inang yang digunakan dalam pengujian. Selain kedua tanaman tersebut, ditanam juga tanaman terong sebagai tanaman untuk pemeliharaan dan perbanyakan kutukebul B. tabaci. Varietas cabai merah dan tomat yang digunakan berturut-turut adalah varietas Ratna dan keriting Bogor. Masing-masing benih tanaman ditaburkan pada permukaan media tanam di baki penyemaian (diameter $20 \mathrm{~cm}$ dan tinggi $5 \mathrm{~cm}$ ) yang mengandung tanah dan pupuk kandang (2:1). Setelah berumur tujuh hari setelah semai, masingmasing sebanyak 1 bibit tanaman (tomat, cabai, dan terong) dipindahtanamkan ke polibag (diameter $25 \mathrm{~cm}$ dan tinggi $30 \mathrm{~cm}$ ) yang sebelumnya telah diisi dengan media tanam yang komposisinya sama dengan media tanam untuk persemaian. Bibit-bibit tersebut kemudian dipelihara hingga berumur 35 hari setelah tanam (HST) yang selanjutnya digunakan untuk pemeliharaan dan pengujian B. tabaci.

\section{Pemeliharaan kutukebul}

Imago $B$. tabaci diambil dari tempat pemeliharaan di rumah kaca Cikabayan, IPB Dramaga. Serangga tersebut terlebih dahulu dilakukan identifikasi sebelum dibiakkan di laboratorium untuk memastikan bahwa kutudaun yang digunakan dalam penelitian ini adalah B. tabaci. Identifikasi dilakukan terhadap kantung pupa yang ditinggalkan oleh imago B. tabaci berdasar- kan ciri morfologinya pada preparat mikroskop. Identifikasi dilakukan dengan menggunakan bantuan kunci identifikasi berdasarkan Martin (1987) dan Watson (2007).

Pupa kutukebul yang diambil dari lapangan dimasukkan ke dalam kurungan plastik berukuran $50 \mathrm{~cm} \times 50 \mathrm{~cm} \times 50 \mathrm{~cm}$ yang di dalamnya telah disediakan tanaman terong yang ditanam dalam polibag. Kutukebul dipelihara hingga menghasilkan keturunan. Ketika memasuki fase pupa, pupa tersebut dimasukkan ke dalam tabung kaca, masing-masing tabung kaca dimasukkan satu individu pupa. Setelah pupa menjadi imago, imago tersebut diamati dengan menggunakan mikroskop binokuler untuk mengetahui jenis kelaminnya. Imago inilah yang nantinya akan digunakan dalam pengujian selanjutnya.

\section{Pengujian dan pengamatan}

Satu imago betina yang baru keluar dari pupa atau nimfa instar akhir diinfestasikan pada tanaman cabai merah dan tomat yang ditanam dalam polibag untuk mengetahui keturunan $B$. tabaci yang dihasilkan tanpa kopulasi. Daun tanaman dikurung dengan kurungan plastik yang berbentuk silinder (tinggi $100 \mathrm{~cm}$ dan diameter $50 \mathrm{~cm}$ ) dan bagian bawah dan atasnya dilapisi kain kasa 25 mesh. Pada bagian tengah tabung tersebut dibuat lubang yang berfungsi untuk memasukkan atau mengeluarkan imago. Imago yang telah diinfestasikan pada masing-masing tanaman dibiarkan selama 24 jam dan kemudian diamati. Apabila imago telah bertelur maka imago dipindahkan ke tanaman tomat atau tanaman cabai yang lain. Demikian seterusnya dan pengamatan dilakukan setiap hari sampai imago betina mati.

Pengujian untuk mengamati reproduksi $B$. tabaci yang berkopulasi sama dengan perlakuan tanpa kopulasi, hanya saja pada tanaman cabai merah dan tomat diinfestasikan satu pasang imago (jantan dan betina). Jika serangga jantan yang diinfestasikan bersama imago betina mati sebelum imago betina mati maka dinfestasikan lagi imago jantan yang baru bersama imago betina. Masingmasing perlakuan diulang 5 kali.

Pengamatan dilakukan setiap hari terhadap jumlah telur yang dihasilkan oleh satu imago betina setiap harinya, masa inkubasi telur, lamanya periode nimfa untuk tiap-tiap instar, pupa, dan imago, serta keberhasilan hidup dari keturunan 
yang dihasilkan baik tanpa kopulasi maupun dengan kopulasi. Selain itu, nisbah kelamin jantan dan betina pada keturunan yang telah menjadi imago juga dihitung.

Lamanya siklus hidup dihitung sejak dari telur hingga imago betina meletakkan telur untuk pertama kalinya. Pada pengamatan siklus hidup, beberapa variabel yang diamati antara lain masa inkubasi telur, lamanya periode nimfa baik instar I, II dan III, periode pupa, dan lamanya perkembangan sejak dari telur hingga menjadi imago.

\section{Analisis data}

Tabulasi data dan pembuatan grafik menggunakan Microsoft Office Excel 2013. Sementara itu, data keperidian, stadium, dan lama hidup $B$. tabaci yang bereproduksi tanpa kopulasi dan dengan kopulasi pada tanaman cabai merah dan tomat diuji dengan uji t independen $(\alpha=0,05)$. Uji t dilakukan dengan menggunakan bantuan program SPSS 22.

\section{HASIL}

\section{Keperidian dan nisbah kelamin}

Perbedaan nyata keperidian imago antara tanaman cabai merah dan tomat ditunjukkan baik tanpa kopulasi maupun dengan kopulasi $(\mathrm{P}<0,05)$ (Tabel 1). Namun, berdasarkan uji T, reproduksi $B$. tabaci dengan kopulasi dan tanpa kopulasi pada kedua jenis tanaman inang tidak menunjukan perbedaan yang nyata, sedangkan jika dibandingkan dengan antar tanaman inang, keperidian B. tabaci pada tanaman tomat lebih tinggi dibandingkan pada tanaman cabai. Ratarata telur yang diletakkan pada tanaman tomat sebanyak 79,85 $\pm 3,13$ butir/imago dan 26,16 \pm 2,24 butir/imago pada tanaman cabai.
Keturunan B. tabaci yang bereproduksi tanpa kopulasi arenotoki seluruhnya adalah jantan, sedangkan B. tabaci yang bereproduksi dengan kopulasi menghasilkan individu jantan dan betina. Nisbah kelamin jantan dan betina B. tabaci yang bereproduksi dengan kopulasi pada tanaman cabai merah dan tomat berturut-turut 1:2,65 dan 1:2,63.

\section{Siklus dan keberhasilan hidup}

Perkembangan nyata keturunan dari imago $B$. tabaci bereproduksi dengan kopulasi lebih cepat dibandingkan dengan yang bereproduksi tanpa kopulasi, namun selisih tersebut sangat kecil dan dari hasil uji t tidak berbeda nyata (Gambar 1). Pada tanaman tomat, lama perkembangan dari masing-masing keturunan yang dihasilkan oleh imago yang bereproduksi tanpa kopulasi maupun berkopulasi juga tidak berbeda nyata berdasarkan uji t pada $\alpha=0,05$. Meskipun demikian, perkembangan keturunan dari imago berkopulasi sedikit lebih lama dibandingkan dengan keturunan imago tanpa kopulasi.

Rata-rata waktu yang diperlukan untuk menyelesaikan satu siklus hidup dan lama stadia setiap instar baik secara reproduksi dengan kopulasi maupun tanpa kopulasi pada tanaman cabai merah dan tomat tidak jauh berbeda, kecuali pada stadium larva instar I yang menunjukkan perbedaan (Gambar 2). B. tabaci yang dipelihara pada tanaman tomat memerlukan waktu 18-33 hari dengan rata-rata $23,19 \pm 0,28$ hari untuk menyelesaikan satu siklus hidupnya, sedangkan siklus hidup $B$. tabaci yang dipelihara pada tanaman cabai berkisar 20-28 hari dengan ratarata $23,50 \pm 0,44$ hari.

Hasil uji t menunjukkan bahwa keberhasilan hidup dari keturunan imago tanpa kopulasi maupun dengan kopulasi yang dibiakkan pada tanaman cabai tidak berbeda nyata. Demikian pula dengan keberhasilan hidup B. tabaci yang dibiakkan pada

Tabel 1. Keperidian imago betina Bemisia tabaci yang bereproduksi tanpa kopulasi dan dengan kopulasi pada tanaman cabai merah dan tomat

\begin{tabular}{lrccc}
\hline \multirow{2}{*}{ Parameter } & \multicolumn{2}{c}{ Cabai $^{1}$} & \multicolumn{2}{c}{ Tomat $^{1}$} \\
\cline { 2 - 5 } & Tanpa kopulasi & \multicolumn{1}{c}{ Kopulasi } & Tanpa kopulasi & Kopulasi \\
\hline Jumlah telur per hari (butir) & $3,05 \pm 0,20 \mathrm{a}$ & $3,84 \pm 0,13 \mathrm{a}$ & $6,99 \pm 0,42 \mathrm{~b}$ & $7,63 \pm 0,72 \mathrm{~b}$ \\
Jumlah telur per imago (butir) & $27,80 \pm 4,09 \mathrm{a}$ & $37,60 \pm 2,79 \mathrm{a}$ & $96,00 \pm 22,77 \mathrm{~b}$ & $122,60 \pm 22,93 \mathrm{~b}$ \\
Masa peneluran (hari) & $9,20 \pm 1,30 \mathrm{a}$ & $9,80 \pm 0,84 \mathrm{a}$ & $13,80 \pm 2,78 \mathrm{~b}$ & $15,40 \pm 2,30 \mathrm{~b}$ \\
Nisbah kelamin (jantan/betina) & - & $1: 2,6$ & - & $1: 2,6$ \\
\hline
\end{tabular}

${ }^{1}$ Angka yang diikuti oleh huruf yang sama pada baris yang sama tidak berbeda nyata berdasarkan uji t $(\alpha=0,05)$. 


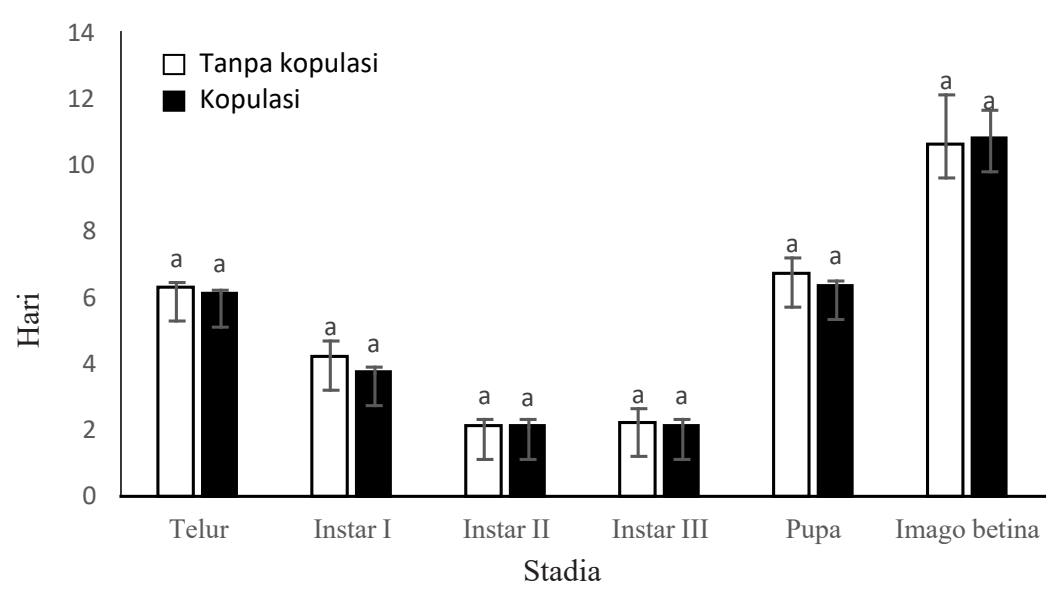

Gambar 1. Stadium telur, nimfa, dan pupa Bemisia tabaci serta lama hidup imago pada tanaman cabai. Grafik batang yang diikuti oleh huruf yang sama pada fase yang sama tidak berbeda nyata berdasarkan uji t $(\alpha=0,05)$.

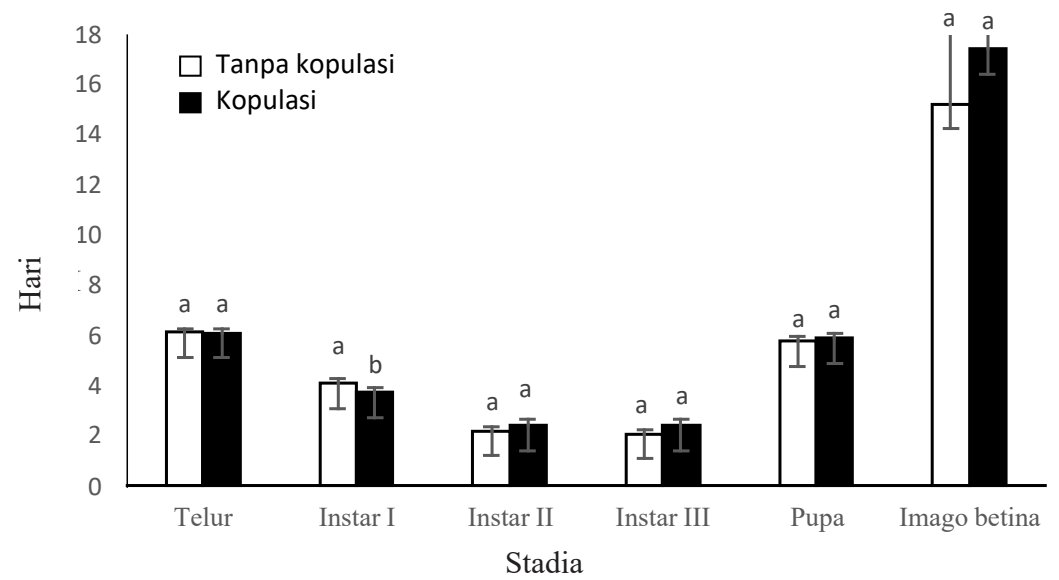

Gambar 2. Stadium telur, nimfa, dan pupa Bemisia tabaci serta lama hidup imago pada tanaman tomat. Grafik batang yang diikuti oleh huruf yang sama pada fase yang sama tidak berbeda nyata berdasarkan uji $\mathrm{t}(\alpha=0,05)$.

tanaman tomat. Keberhasilan hidup keturunan $B$. tabaci yang bereproduksi dengan kopulasi pada tanaman tomat sedikit lebih tinggi dibandingkan dengan keturunan dari imago yang bereproduksi tanpa kopulasi. Hal ini dapat dilihat dari persentase penetasan telur dan nimfa yang berhasil hidup sampai ke fase pupa dan imago, sedangkan pada tanaman cabai, keberhasilan hidup antara keturunan B. tabaci yang bereproduksi tanpa kopulasi dan dengan kopulasi relatif sama.

\section{PEMBAHASAN}

Keperidian B. tabaci baik yang bereproduksi dengan kopulasi maupun tanpa kopulasi pada tanaman tomat lebih tinggi dibandingkan pada tanaman cabai. Menurut Harris et al. (2001) kemampuan imago B. tabaci dalam menghasilkan telur dan siklus hidupnya dipengaruhi oleh jenis tanaman inang dan kondisi suhu. Indrayani \& Sulistyowati (2005) melaporkan bahwa B. tabaci memiliki preferensi tinggi untuk meletakkan pada tanaman inang yang daunnya berbulu. Adapun jumlah telur yang diletakkan $B$. tabaci baik yang bereproduksi dengan kopulasi maupun tanpa kopulasi pada tanaman tomat tidak berbeda jauh dengan yang diletakkan pada tanaman kedelai. Menurut Badri (1983), imago betina yang dipelihara pada tanaman kedelai di Bogor dapat meletakkan telur sebanyak $125,0 \pm 40,0$ butir oleh induk yang bereproduksi dengan kopulasi, sedangkan induk yang bereproduksi tanpa kopulasi sebanyak 99,0 $\pm 12,0$ butir.

Kelompok imago $B$. tabaci yang reproduksinya tanpa kopulasi arenotoki hanya menghasilkan keturunan jantan, sedangkan kelompok imago yang reproduksinya dengan kopulasi menghasilkan 
keturunan jantan dan betina. Reproduksi B. tabaci adalah haplodiploid, jika tanpa pembuahan menghasilkan keturunan jantan dan jika dengan pembuahan menghasilkan keturunan betina. Beberapa peneliti melaporkan nisbah kelamin jantan dan betina yang berbeda-beda. Menurut Hilje \& Morales (2003), perbandingan nisbah kelamin B. tabaci bervariasi antara 1:1 sampai 1:3, sedangkan menurut Hidayat et al. (2017), perbandingan nisbah kelamin antara $B$. tabaci biotipe $\mathrm{B}$ dan non-B pada tanaman cabai adalah 1:2.

Perbandingan nisbah kelamin dalam populasi B. tabaci bergantung pada temperatur dan lama hidup imago jantan (Ewusie 2008). Brown (2007) melaporkan bahwa dalam suatu populasi $B$. tabaci terjadi pengaturan dalam perbandingan jantan dan betina. Ketika kelimpahan atau jumlah betina pada populasi tinggi maka betina akan menghasilkan keturunan jantan dan sebaliknya. Pola reproduksi kutukebul tersebut memiliki kemiripan dengan trips, yaitu haplodiploid. Adanya pengaruh komposisi populasi dari trips dapat menyebabkan perubahan dari cara reproduksinya. Ding et al. (2018) melaporkan bahwa pada trips spesies Frankliniella occidentalis (Pergande) terjadi pergantian cara reproduksi dari partenogenesis ke dengan kopulasi atau sebaliknya bergantung pada komposisi populasi.

Siklus hidup B. tabaci pada tanaman tomat berkisar 18-33 hari, sedangkan pada tanaman cabai berkisar 20-28 hari. Imago B. tabaci yang dipelihara pada tanaman tomat hidup lebih lama dibandingkan pada tanaman cabai. Pada umumnya mortalitas tertinggi terjadi pada fase nimfa, terutama nimfa instar I dan mortalitas terendah terjadi pada fase pupa. Mortalitas pada nimfa terjadi sebelum tubuh nimfa menebal setelah ganti kulit. Setelah ganti kulit tubuh tetap pipih dan transparan hingga beberapa hari kemudian tubuh mengering.

Perbedaan siklus hidup dan kelangsungan hidup B. tabaci dapat dipengaruhi oleh suhu. Menurut Subagyo \& Hidayat (2014), siklus hidup B. tabaci pada tanaman cabai pada suhu 24 dan $29{ }^{\circ} \mathrm{C}$, yaitu 25 dan 21 hari, sedangkan menurut Chintkuntlawar et al. (2016) siklus hidup $B$. tabaci pada tanaman cabai pada suhu $24-31{ }^{\circ} \mathrm{C}$ berkisar 20-23 hari. Naranjo \& Ellsworth (2005) juga melaporkan bahwa salah satu faktor yang mempengaruhi aspek biologi dan kelangsungan hidup B. tabaci adalah tanaman inang. Hal tersebut berkaitan dengan kuantitas dan kualitas makanan bagi pertumbuhan dan perkembangan serangga. Ratna et al. (2009) menyatakan bahwa beberapa faktor yang dapat memengaruhi ketertarikan $B$. tabaci pada tanaman inang di antaranya, yaitu ukuran daun, kerapatan bulu daun, kandungan gula pada kelenjar trikoma, kekerasan jaringan tanaman, dan kandungan nutrisi pada tanaman.

\section{KESIMPULAN}

Keperidian B. tabaci yang bereproduksi dengan kopulasi dan tanpa kopulasi pada tanaman tomat lebih tinggi dibandingkan pada tanaman cabai. Tidak terdapat perbedaan siklus hidup dan nisbah kelamin B. tabaci yang bereproduksi dengan kopulasi dan tanpa kopulasi baik pada tanaman cabai maupun tomat. Informasi tersebut tersebut dapat dimanfaatkan sebagai dasar dalam pengelolaan hama kutu kebul yang juga merupakan vektor virus pada tanaman cabai dan tomat.

\section{DAFTAR PUSTAKA}

Badri IB. 1983. Identification of Aleyrodidae on Soybean from Two Location in West Java and Some Bionomics of Bemisia tabaci Genn. (Hemiptera: Aleyrodidae) on The Three Soybean Varietas. Bogor: SEAMEO-Biotrop, Regional Center for tropical Biologi Indonesia.

Bonato O, Abdelslam K, Fargues J. 2006. Breve note - Short note. Mise en evidence experimentale de la parthenogenese arrhenotoque chez Bemisia tabaci biotype Q (Homoptera: Aleyrodidae). Annales de la Société Entomologique de France 42:255-256. doi: https://doi.org/10.1080/00379 271.2006.10700629.

Bos L. 1981. Plant Disease and Vector. New York: Academia Press.

Brown JK. 2007. The Bemisia tabaci complex: Genetic and phenotypic variability drives Begomovirus spread and virus diversification. Tersedia pada:http://www.apsnet.org/online/feature/ btabaci. [diakses 14 Juni 2009]. doi: https://doi. org/10.1094/APSnetFeature/2007-0107. 
Byrne DN, Thomas S. 1991. Whitefly biology. Annual Review of Entomology 36:431-457. doi: https:// doi.org/10.1146/annurev.en.36.010191.002243.

Byrne FJ, Devonshire AL. 1996. Biochemical evidence of haplodiploidy in the whitefly Bemisia tabaci. Biochemical Genetics 34:93-105. doi: https://doi.org/10.1007/BF02396243.

Chintkuntlawar PS, Pramanik A, Chatterjee H. 2016. Biology and physical measurements of whitefly, Bemisia tabaci (Gennadius) on chili in West Bengal, India. International Journal of Agricultural Science 8:2063-2065.

Costa HS, Brown JK. 1991. Variation in biological characteristics and esterase patterns among populations of Bemisia tabaci, and the association of one population with silverleaf symptom induction. Entomologia Experimentalis et Applicata 61:211-219. doi: https://doi. org/10.1111/j.1570-7458.1991.tb01553.x.

Ding T, Hsin C, Ayhan G, Yulin G, Bin Z. 2018. Demographic analysis of arrhenotokous parthenogenesis and bisexual reproduction of Frankliniella occidentalis (Pergande) (Thysanoptera: Thripidae). Nature Scientific Report 8:3346. doi: https://doi.org/10.1038/ s41598-018-21689-z.

Ewusie E. 2008. Potential and Prospect of Strip Copping in The Management of Cassava Whitefly Bemisia tabaci in Peri-Urban Agroecosistems. Thesis. Texas: Texas Tech University.

Gangwar RK, Gangwar C. 2018. Lifecycle, ditribution, nature of damage and economic importance of whitefly, Bemisia tabaci (Gennadius). Acta Scientific Agriculture 2:36-39.

Gullan PJ, Martin JH. 2009. Sternorrhyncha. Di dalam: Resh VH, Cardé RT (Eds.), Encyclopedia of Insects. $2^{\text {nd }}$ Edition. Academic Press. doi: https://doi.org/10.1016/B978-0-12-374144-8. X0001-X.

Harris KF, Smith OP, Duffus JE. 2001. VirusInsectplant Interactions. San Diego: Academic Press.

Hidayat P, Kurniawan HA, Afifah L, Triwidodo H. 2017. Siklus hidup dan statistik demografi kutukebul Bemisia tabaci (Gennadius) (Hemiptera: Aleyrodidae) biotipe B dan non-B pada tanaman cabai (Capsicum annum L.). Jurnal Entomologi Indonesia 4:143-151. doi: https://doi.org/10.5994/jei.14.3.87.

Hilje L, Morales J. 2003. Whitefly bioecology and management in Latin America. Tersedia pada: http://orton.catie.ac.cr/repdoc/A35521.PDF. [diakses 19 September 2010].

Indrayani IGAA, Sulistyowati E. 2005. Pengaruh kerapatan bulu daun pada tanaman kapas terhadap kolonisasi Bemicia tabaci Gennadius. Jurnal Penelitian Tanaman Industri 11:101-106. doi: https://doi.org/10.21082/jlittri.v11n3.2005.101106.

Kalshoven LGE. 1981. The Pests of Crops in Indonesia. Laan PA van der, penerjemah. Jakarta: Ichtar Baru-van Hoeve. Terjemahan dari: De Plagen van de Cultuurgewassen In Indonesie.

Martin JH. 1987. An identification guide to common whitefly pest species of the world (Homoptera: Aleyrodidae). Tropical Pest Management 33:298-322. doi: https://doi. org/10.1080/09670878709371174.

Naranjo SE, Ellsworth PC. 2005. Mortality dynamics and population regulation in Bemisia tabaci. Entomologia Experimentalis et Applicata 116:93-108. doi: https://doi.org/10.1111/j.15707458.2005.00297.x.

Narendra AAGG, Phabiola TA, Yuliadhi KA. 2017. Hubungan antara populasi kutukebul (Bemisia tabaci) (Gennadius) ( Hemiptera: Aleyrodidae) dengan insiden penyakit kuning pada tanaman tomat (Solanum lycopersicum Mill.) di Dusun Marga Tengah, Desa Kerta, Kecamatan Payangan, Bali.JurnalAgroekoteknologiTropika 6:339-348. Ratna Y, Untung K, Trisyono YA, Indradewa D. 2009. Resurgensi serangga hama karena perubahan fisiologi tanaman dan serangga sasaran setelah aplikasi insektisida. Jurnal Perlindaungan Tanaman 15:55-64.

Santoso TJ, Hidayat SH, Herman M, Aswidinoor, Sudarsono. 2008. Identitas dan keragaman genetik Begomovirus yang berasosiasi dengan penyakit keriting pada tomat berdasarkan teknik polymerase chain reaction (PCR)-restriction fragmen length polymorphism (RFLP). Jurnal AgroBiogen 4:9-17. doi: https://doi. org/10.21082/jbio.v4n1.2008.p9-17.

Sebayang L. 2013. Teknik Pengendalian Penyakit Kuning pada Tanaman Cabai. Sumatra Utara: Balai Pengkajian Teknologi Pertanian Sumatra Utara.

Subagyo VNO, Hidayat P. 2014. Neraca kehidupan kutukebul Bemisia tabaci (Gennadius) (Hemiptera: Aleyrodidae) pada tanaman cabai merah dan gulma babadotan pada suhu $25^{\circ} \mathrm{C}$ dan $29^{\circ} \mathrm{C}$. Jurnal Entomologi Indonesia 11:1118. doi: https://doi.org/10.5994/jei.11.1.11.

Sudiono, Yasin N, Hidayat SH, Hidayat P. 2005. Penyebaran dan deteksi molecular virus Gemini penyebab penyakit kuning pada tanaman cabai di Sumatra. Jurnal HPT Tropika 52:113-121.

Watson GV. 2007. Identification of Whiteflies (Hemiptera: Aleyrodidae). Kuala Lumpur: APEC Re-enctry. 